\title{
Analysis of Polymorphisms on GH-MspI and IGF1-SnaBI Loci in Five Turkish Native Cattle Breeds
}

\author{
Yasemin Öner $^{1 *}$, Onur Yılmaz ${ }^{2}$, Candan Eriş $^{1}$, Nezih Ata $^{2}$, Cihan Ünal $^{3}$, Seyrani Koncagül ${ }^{4}$ \\ ${ }^{1}$ Department of Animal Science, Biometry and Genetics, Faculty of Agriculture, University of Uludağ, 16059 Bursa, Turkey \\ ${ }^{2}$ Department of Animal Science, Biometry and Genetics, Faculty of Agriculture, Adnan Menderes University, 09100 Aydin, Turkey \\ ${ }^{3}$ Department of Zootechnics, Faculty of Veterinary Medicine, Uludağ University 16059 Nilufer/Bursa, Turkey \\ ${ }^{4}$ Department of Animal Science, Faculty of Agriculture, Ankara University, 06110 Ankara, Turkey
}

\section{A R T I C LE IN F O}

\section{Research Articles}

Received 23 February 2018

Accepted 03 September 2018

Keywords:

Cattle

$\mathrm{GH}$

IGF1

Genetic diversity

Polymorphism

\begin{tabular}{l}
\hline Corresponding Author: \\
\hline E-mail: aseminoner@yahoo.com
\end{tabular}

\section{A B S T R A C T}

Growth Hormone (GH) and Insulin like Growth Factor-I (IGF1) are members of somototrophine axis pathway. They play a role in key on several mechanisms such as postnatal growth, cell differentiation and metabolism. Due to their vital importance, polymorphisms on the genes coding are worth to be understood. In this study five native cattle breeds (Native Southern Yellow (NSY), South Anatolian Red (SAR), Anatolian Grey (AG), Native Black (NB), East Anatolian Red (EAR) were investigated by PCRRFLP method for GH-MspI and IGF1-SnaBI loci. 198 and 194 samples were analyzed for GH-MspI and IGF1-SnaBI loci, respectively. In both two loci two alleles and three genotypes were observed. Predominant alleles were A and B for GH-MspI locus IGF1SnaBI loci, respectively. Frequencies of A and B alleles were calculated between 0.400 0.875 and 0.846-0.903 for GH-MspI locus IGF1-SnaBI loci, respectively. While among investigated population only EAR population was at Hardy-Weinberg equilibrium for IGF1-SnaBI locus, for GH-MspI only, in SAR population no deviation from HardyWeinberg equilibrium.

Türk Tarım - Gıda Bilim ve Teknoloji Dergisi, 6(10): 1353-1356, 2018

\section{Beş Yerli Türk Sığır Irkında GH-MspI and IGF1-SnaBI Lokuslarındaki Polimorfizmlerin Analizi}

\section{A K A L E B İ L G İ S İ}

\section{Araştırma Makalesi}

Geliş 23 Şubat 2018

Kabul 03 Eylül 2018

Anahtar Kelimeler:

Siğgr

GH

IGF1

Genetik çeşitlilik

Polimorfizm

\section{Ö Z}

Büyüme Hormonu (GH) ve İnsülin Benzeri Büyüme Faktörü-I (IGF-I) somatotropin axis yolağının üyeleridirler. Doğum sonrası gelişim, hücre farklılaşması ve metabolizmada gibi mekanizmalarda anahtar rol oynarlar. Hayati önemlerinden dolayı bunları kodlayan genlerin anlaşılmaları da gereklidir. Bu çalışmada beş yerli sı̆̆ır ırkı (Yerli Güney Sarısı (YGS), Güneydoğu Anadolu Kırmızısı (GAK), Boz Irk (BI), Yerli Kara (YK) ve Doğu Anadolu Kırmızısı (DAK) GH-MspI ve IGF1-SnaBI locusları bakımından PCR-RFLP yöntemi ile incelenmiştir. GH-MspI lokusu için 198, IGF1-SnaBI lokusu için 194 örnek analiz edilmiştir. Her iki lokusta iki allel ve üç genotip gözlenmştir. GH-MspI ve IGF1SnaBI lokusları için predominant alleler sırasıyla A ve B olarak bulunmuştur. GH-MspI ve IGF1-SnaBI locusları için A ve B allelerinin frekansları sırasıyla $0,400-0,875$ ve 0,846-0,903 arasında hesaplanmıştır. İncelenen populasyonlardan sadece DAK IGF1SnaBI bakımından Hardy-Weinberg dengesindeyken, GH-MspI lokusu için sadece GAK populasyonunda Hardy-Weinberg dengesinden sapma gözlenmiştir.

${ }^{\text {*Sorumlu Yazar: }}$

E-mail: aseminoner@yahoo.com 


\section{Introduction}

Developments in molecular genetics and software techniques have allowed investigating and understanding genomic regions related to production traits and breed differentiation (Plath-Gabler et al., 2001). As well known genetic improvement for a particular trait is quite complex and expensive process. Using molecular genetic markers gives promises to high selection accuracy and shorter generation interval which can reduce time and money consumed to profitability in animal production. With regard to breed differentiation these markers are accepted as estimation past, current and future population structure. Thus, it is possible to obtain data to use for designing breeding and conservation schemes.

Growth Hormone (GH) and Insulin like Growth Factor-I (IGF1) are two of the most important members of somototrophine axis pathway and assume important for growth, cell differentiation, milk production and energy metabolisms. Polymorphisms may alter quality and quantity of gene's products therefore, mutations occurred in these two genes have been investigated intensively. Growth Hormone (GH) and Insulin like Growth Factor-I (IGF1) genes are located on $19^{\text {th }}(\mathrm{NCBI}, 2018 \mathrm{a})$ and $5^{\text {th }}$ chromosomes (NCBI, 2018b) of bovine genome, respectively. A $\mathrm{C} \rightarrow \mathrm{G}$ transvertion in $3^{\text {th }}$ intron of $\mathrm{GH}$ gene leads to a MspI recognizing site (Hoj et al., 1993) and a $\mathrm{T} \rightarrow \mathrm{C}$ transition at 5' flanking region of IGF1 gene causes a SnaBI recognizing site (Ge et al., 1997). These two SNPs have been focused because of potential effects on productive traits and suggested relation of different alleles with Bos taurus and Bos indicus originated cattle breeds.

In this study investigation of all GH-MspI and IGF1SnaBI allelic distribution among five native cattle breeds is aimed.

\section{Material and Methods}

Sampling and DNA Isolation

The study was approved by the Ethics Committee of Uludag University (UUHADYEK), (approval date: 01/09/2015; no: 2015-10/10). Blood samples were collected from original regions of five native cattle breeds.

Genomic DNA was extracted with a genomic DNA extraction kit (NucleoSpin Blood, Macherey-Nagel $\mathrm{GmbH} \& \mathrm{Co} . \mathrm{KG})$ according to the instructions provided in the manual. Afterward, quantification and qualification of DNA were controlled using NanoDrop 2000 (Thermo Scientific, USA).

\section{PCR - RFLP Analysis}

PCR-RFLP analyses were preformed according to $\mathrm{Ge}$ et al. (1997) and Dybus (2002) (Table 1)

\section{Statistical Analysis}

Gene and genotype frequencies expected and observed heterozygoties ( $\mathrm{He}$ and $\mathrm{Ho}$ ), and Chi-square $(\chi 2)$ values were calculated by POPGENE32 software program (Yeh 2000). Dendrogram was drawn by MEGA 7.18 according to Kumar et al. (2016).

\section{Results and Discussion}

Amplification of target region from $\mathrm{GH}$ and IGF1 genes 329 bp and 249 bp PCR products were obtained, respectively. Two alleles named A (224 bp and $105 \mathrm{bp}$ ) and B (329 bp) were observed for GH- MspI locus and A (223 bp and 26 bp) and B (249 bp) (Figure 1).

Gene and genotype frequencies expected and observed heterozygotes ( $\mathrm{He}$ and Ho) were given in Table 2.

Table 1 Primer sequences, temperature for annealing step, PCR product sizes (bp) and restriction enzymes were used

\begin{tabular}{c|lcccc}
\hline Loci & \multicolumn{1}{|c}{ Primer sequencing $\left(5^{\prime} \rightarrow 3^{\prime}\right)$} & Annealing $\left({ }^{\circ} \mathrm{C}\right)$ & PCR products & RE & Literature \\
\hline \multirow{2}{*}{ IGF1 } & $\begin{array}{l}\text { ATTACAAAGCTGCCTGCCCC } \\
\text { ACCTTACCCGTATGAAAGGAATATACGT }\end{array}$ & 58 & $249 \mathrm{bp}$ & SnaBI & Ge et al. \\
& $\begin{array}{l}\text { ACCACGGGCAAGAATGAGGC } \\
\text { CH }\end{array}$ & 52 & $329 \mathrm{bp}$ & MspI & Dybus (2002) \\
\hline
\end{tabular}

Table 2 Population parametres for GH-MspI and IGF1-SnaBI loci

\begin{tabular}{|c|c|c|c|c|c|c|c|c|c|}
\hline \multirow{2}{*}{ Locus } & \multirow{2}{*}{$\mathrm{n}$} & \multicolumn{2}{|c|}{ Allele frequencies } & \multicolumn{3}{|c|}{ Genotype frequencies (\%) } & \multirow{2}{*}{$\mathrm{He}$} & \multirow{2}{*}{ Ho } & \multirow{2}{*}{$\chi^{2}$} \\
\hline & & $\mathrm{A}$ & $\mathrm{B}$ & AA & $\mathrm{AB}$ & BB & & & \\
\hline \multicolumn{10}{|c|}{ Native Southern Yellow (NSY) } \\
\hline GH & 40 & 0.625 & 0.375 & 40 & 45 & 15 & 0.450 & 0.469 & $0.064^{\mathrm{ns}}$ \\
\hline IGF1 & 39 & 0.154 & 0.846 & 7.70 & 15.40 & 76.90 & 0.154 & 0.260 & $6.526^{*}$ \\
\hline \multicolumn{10}{|c|}{ Native Black (NB) } \\
\hline $\mathrm{GH}$ & 40 & 0.400 & 0.600 & 17.50 & 45 & 37.50 & 0.450 & 0.480 & $0.156^{\mathrm{ns}}$ \\
\hline IGF1 & 39 & 0.154 & 0.846 & 15 & 0 & 85 & 0.000 & 0.260 & $39.000 * * *$ \\
\hline \multicolumn{10}{|c|}{ Anatolian Grey (AG) } \\
\hline GH & 40 & 0.638 & 0.363 & 42.50 & 42.50 & 15 & 0.425 & 0.462 & $0.259^{\mathrm{ns}}$ \\
\hline IGF1 & 36 & 0.097 & 0.903 & 8.33 & 2.78 & 88.89 & 0.028 & 0.176 & $25.508 * * *$ \\
\hline \multicolumn{10}{|c|}{ East Anatolian Red (EAR) } \\
\hline GH & 40 & 0.875 & 0.125 & 77.50 & 20 & 2.50 & 0.200 & 0.219 & $0.294^{\mathrm{ns}}$ \\
\hline IGF1 & 40 & 0.113 & 0.888 & 2.5 & 17.5 & 80 & 0.175 & 0.200 & $0.611^{\mathrm{ns}}$ \\
\hline \multicolumn{10}{|c|}{ South Anatolian Red (SAR) } \\
\hline GH & 38 & 0.645 & 0.355 & 34.20 & 60.50 & 5.30 & 0.605 & 0.428 & $3.921^{*}$ \\
\hline IGF1 & 40 & 0.113 & 0.888 & 5.13 & 12.82 & 82.05 & 0.125 & 0.200 & $5.596^{*}$ \\
\hline
\end{tabular}


$A B \quad A B \quad A B \quad A A \quad A B \quad B B \quad M$

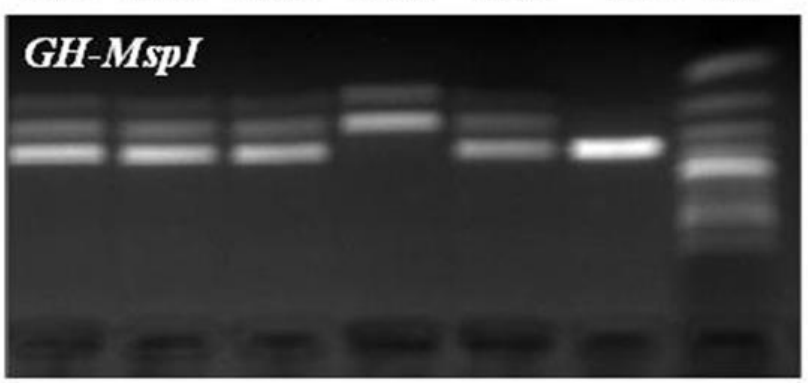

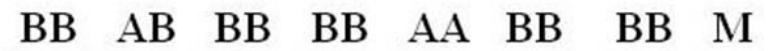

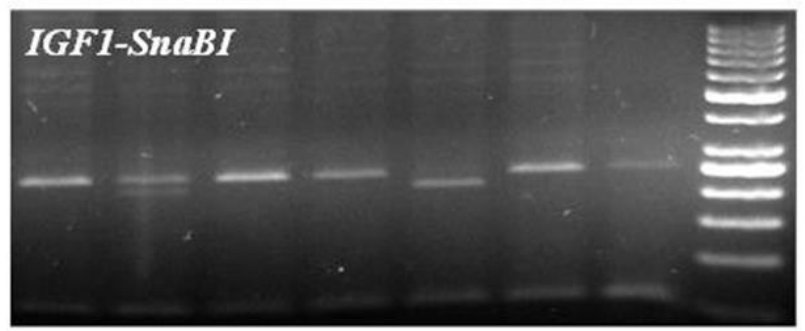

Figure 1 Electrophoretic illustration of GH-MspI and IGF1-SnaBI loci. (M: Marker, for GH-MspI 100bp, for IGF1-SnaBI 50 bp)

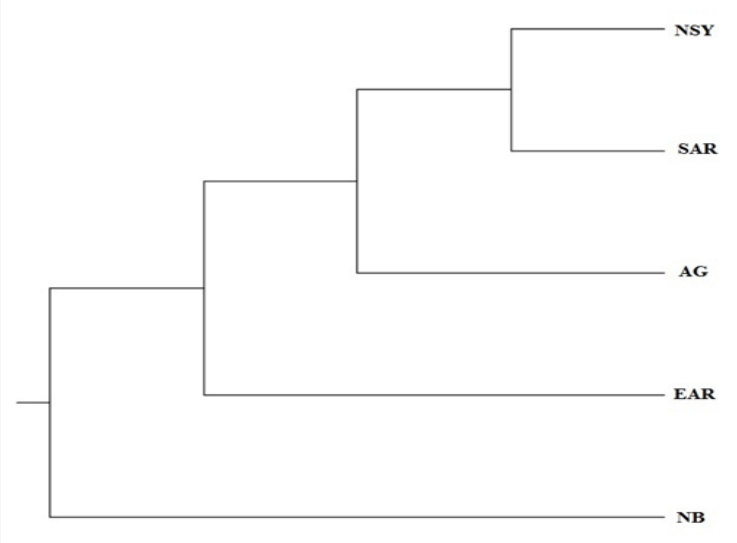

Figure 2 Dendrogram drawn by PCR-RFLP results of GH-MspI and IGF1-SnaBI loci.

Allele and genotype frequencies observed for the two loci were concordance with the other authors from different countries and studies carried out in Turkish native cattle breeds (Yao et al., 1996; Zhou et al., 2005; Curi et al., 2005; Özkan et al., 2009; Akış et al., 2010; Reyna et al., 2010).

Wright's F-statistic $\left(\mathrm{F}_{\mathrm{IT}}, \mathrm{F}_{\mathrm{IS}}, \mathrm{F}_{\mathrm{ST}}\right)$ values were estimated at $-0.020,0.079$ and 0.098 for GH-MspI and $0.560,0.563$ and 0.005 IGF1-SnaBI loci. Lower heterozygosity level in IGF1-SnaBI locus is indicated from these Fs values (Table 2).

Different allelic distribution for GH-MspI and IGF1SnaBI loci among B. indicus and B. taurus related breeds has been reported by several authors (Lagziel et al. 2000; Curi et al. 2005; Sodhi et al. 2007). It is suggested that B allele was associated with $B$. taurus and B. indicus for GH-MspI and IGF1-SnaBI loci, respectively. According to PCR-RFLP analysis A allele was predominant at GHMspI locus except for NB population. For IGF1-SnaBI locus B allele was found as prevalent among all breeds as concordance with the other studies previously. Although in some studies this allele was found as fixed (Curi et al., 2005; Li et al., 2006) or nearly fixed (Reyna et al., 2010; Yurnatis et al., 2017), in some B. taurus orjinated breed populations it has reached till 0.90 (Lirón et al., 2012).

Due to origin related allelic distribution we also drew a UPGMA dendrogram (Figure 2) by using GH-MspI and IGF1-SnaBI allele frequencies.

The dendrogram obtained was quite similar to those of the others by drawn using autosomal (Özşensoy et al., 2010) and unipaternal markers (Özdemir et al., 2009; Özşensoy et al., 2014).

According to dendrogram obtained from PCR-RFLP results while SAR and NSY breeds clustered together, AG located near to these two breeds. Native Black breed separated from the rest of the breeds.

While IGF1-SnaBI locus were found influential on carcass and growth traits (Curi et al., 2005; Reyna et al., 2010; Nicolini et al., 2013; Siadkowsca et al., 2006; Szewzuk et al., 2013), no relationship were found with milk production traits in neither in Montbeliarde and Iranian Holstein breeds (Mehmenavaz et al., 2010; Szewzuk, 2006) nor NSY and SAR breeds from Turkey (Akış et al., 2010) Associations with GH-MspI polymorphism has been reveal not only for milk (Hoj et al., 1993; Yao et al., 1996; Lagziel et al., 1999; Zhou et al., 2005; Pawar et al., 2007; Rincón et al., 2013) and meat production traits (Unanian et al., 2000; Hernández et al., 2016) but also has been revealed for fertility and reproduction (Unanian et al., 2002; Gorbani et al., 2009; Mullen et al., 2011; Arango et al., 2014; Öner et al., 2017).

These investigated two loci may be important for phenotypic traits due to their critical roles in metabolic activities. In our study due to lack of the phenotypic data it has not been possible for any association analysis. However, it is clear that at least GH-MspI locus exhibit an appropriate distribution in order to design association analysis in Turkish native cattle breeds. Further studies should be carried out to figure out functional importance of these mutations and relationships with phenotypic traits. On the other hand, these two loci might be used in diversity studies with more RFLP loci. By using more suitable RFLP loci accuracy of phylogenetic trees observed may be increased.

\section{Acknowledgements}

This work was financially supported by the Scientific Research Council of Uludag University (Project number: KUAP 2015/80).

\section{References}

Akış I, Oztabak K, Gonulalp I, Mengi A, Ün C. 2010. IGF-1 and IGF-1R Gene Polymorphisms in East Anatolian Red and South Anatolian Red Cattle Breeds. Genetika., 46(4):497501.

Arango J, Echeverri JJ, López A. 2014. Association between a polymorphism in intron 3 of the bovine growth hormone gene and growth traits in Holstein heifers in Antioquia. Genet. Mol. Res., 13: 6191-6199. 
Curi RA, Oliveira HND, Silveira AC, Lopes CR. 2005. Effects of polymorphic microsatellites in the regulatory region of IGF1 and GHR on growth and carcass traits in beef cattle. Anim. Genet., 36: 58-62. DOI: 10.1111/j.13652052.2004.01226.x

Dybus A. 2002. Associations of growth hormone $(\mathrm{GH})$ and prolactin (PRL) genes polymorphisms with milk production traits in Polish Black-andWhite cattle. Anim. Sci. Pap. Rep., 20: 203-212.

Ge W, Davis ME, Hines HC.1997. Two SSCP alleles detected in the 5'-flanking region of bovine IGF1 gene. Anim. Genet., 28: 155-156.

Gorbani A, Torshizi RV, Bonyadi M, Amirinia C. 2009. Restriction fragment length polymorphism of bovine growth hormone gene intron 3 and its association with testis biometry traits in Iranian Holstein bull. Afr. J. Microbiol. Res., 3 (11): 809-814.

Hernández N, Martínez-González JC, Parra-Bracamonte GM, Sifuentes-Rincón AM López-Villalobos N, Morris ST, Briones-Encinia F, Ortega-Rivas E, Pacheco-Contreras VI, Meza-García LA. 2016. Association of polymorphisms in growth hormone and leptin candidate genes with live weight traits of Brahman cattle. Genet. Mol. Res., 15 (3): gmr.15038449

Hoj S, Fredholm M, Larsen NJ, Nielsen VH. 1993. Growth hormone gene polymorphism associated with selection for milk fat production in lines of cattle. Anim. Genet., 24: 9196.

Kumar S, Stecher G, Tamura K. 2016. MEGA7: Molecular Evolutionary Genetics Analysis Version 7.0 for Bigger Datasets. Mol. Biol. Evol., 33(7): 1870-1874.

Lagziel A, Lipkin E, Ezra E, Soller M, Weller JI: An MspI polymorphism at the bovine growth hormone (bGH) gene is linked to a locus affecting milk protein percentage. Anim Genet, 30 (4): 296-299, 1999.

Lagziel A, Denise S, Hanotte O, Dhara S, Glazko V, Broadhead A, Davoli R, Russo V, Soller M. 2000. Geographic and breed distribution of an MspI PCR-RFLP in the bovine growth hormone (bGH) gene. Anim. Genet., 31:210-213.

Mehmannavaz Y, Amirinia C, Bonyadi M, Torshizi RV. 2010. Association of IGF-1 gene polymorphism with milk production traits and paternal genetic trends in Iranian Holstein bulls. Afr. J. Microbiol. Res., 4(1): 110-114.

Mullen MP, Lynch CO, Waters SM, Howard DJ, O'Boyle P, Kenny DA, Buckley F, Horan B, Diskin MG. 2011. Single nucleotide polymorphisms in the growth hormone and insulin-like growth factor-1 genes are associated with milk production, body condition score and fertility traits in dairy cows. Genet. Mol. Res., 10: 1819-1830.

Nicolini P, Carriquiry M, Meikle A. 2013. A polymorphism in the insulin-like growth factor 1 gene is associated with postpartum resumption of ovarian cyclicity in HolsteinFriesian cows under grazing conditions. Acta Vet Scand. 2013; 55(1): 11.

NCBI.2018a. GH1 growth hormone 1 [Bos taurus (cattle)], https://www.ncbi.nlm.nih.gov/gene/280804

NCBI.2018b. IGF1 insulin like growth factor 1 [Bos taurus (cattle)], https://www.ncbi.nlm.nih.gov/gene/281239

Pawar RS, Tajane KR, Joshi CG, Rank DN, Bramkshtri BP. 2007. Growth hormone gene polymorphism and its association with lactation yield in dairy cattle. Indian $\mathrm{J}$. Anim. Sci., 77 (9): 884-888.

Plath - Gabler A, Gabler C, SinowatzF, Berisha B, Schams D. 2001. The expression of the IGF family and GH receptor in the bovine mammary gland. J. Endocrinol., 168: 39-48.

Reyna XF, Montoya HM, Castrelln VV, Rincn AMS, Bracamonte MP, Vera WA. 2010.

Polymorphisms in the IGF1 gene and their effect on growth traits in Mexican beef cattle. Genet. Mol.Res., 9: 875-883. DOI: $10.4238 /$ vol9-2gmr745
Rincón JC, López-Herrera A, Echeverri JJ. 2013. Effect of two single nucleotide polymorphisms on milk yield and composition. Genet. Mol. Res., 12: 995-1004.

Siadkowska E, Zwierzchowski L, Oprządek j, Strzałkowska N, Bagnicka E, Krzyżewski J. 2006. Effect of polymorphism in IGF-1 gene on production traits in Polish Holstein-Friesian cattle. Anim. Sci. Pap. Rep., 24(3): 225-237.

Sodhi M, Mukesh M, Prakash B, Mishra B, Sobti R, Karn S, Singh S, Ahlawat S. 2007. MspI allelic pattern of bovine growth hormone gene in Indian Zebu cattle (Bos indicus) breeds. Biochem. Genet., 45: 145-153.

Szewczuk M. 2006. Association of single nucleotide polymorphisms in genes coding insulin-like growth factor 1 system and milk production traits in Montbeliarde cows. S. Afr. J. Anim. Sci.., 46: 191-195.

Szewczuk M, Zych S, Wójcik J, Czerniawska-Piątkowska E. 2013. Association of two SNPs in the coding region of the insulin-like growth factor 1 receptor (IGF1R) gene with growth-related traits in Angus cattle. J. Appl. Genet., 54, 305-308.

Oner Y, Yılmaz O, Okut H, Ata N, Yılmazbaş-Mecitoğlu G, Keskin A. 2017. Associations Between GH, PRL, STAT5A, OPN, PIT-1, LEP and FGF2 Polymorphisms and Fertility in Holstein-Friesian Heifers. Kafkas Univ. Vet. Fak. Derg., 23 (4): 527-534

Ozdemir M, Dogru U, Ciftci M. 2009. Polymorphism on mtDNA D-loop and ND5 Regions Among Turkish Native Cattle Breeds Assessed by PCR-RFLP. JAAR., 36(1):37-40.

Özkan E, Soysal Mİ, Dinç H, Sönmez G, Okyar M, Togan İ. 2009. Türkiye sığır ırklarında büyüme hormonu AluI ve MspI polimorfizminin PZR-RFLP yönteminin kullanılarak belirlenmesi. 6. Ulusal Zootekni Kongresi, 24-26 Haziran, Erzurum, 93-102.

Özşensoy Y, Kurar E, Doğan E, Bulut Z, Altunok V, Işık A, Çamlıdağ A, Nizamlığlu A. 2010. Türkiye'de Bulunan Bazı Yerli Sığır Irklarının STR Markörler ile Genetik Karakterizasyonu. BİBAD., 3: 163-171.

Özşensoy Y, Kurar M, Bulut Z, Nizamlioğlu MY. 2014. Y chromosome analysis of native Turkish cattle breeds by microsatellite markers. Turkish Journal of Biology., 38: 388395.

Unanian MM, Barreto CC, Freitas ARD, Cordeiro CMT, Josahkian LA. 2000. Associations between growth hormone gene polymorphism and weight traits in Nellore bovines. R. Bras. Zootec.,29: 1380-1386.

Unanian MM, Barreto CC, Cordeiro CMT, Freitas AR, Josahkian LA. 2002. Possible association between bovine growth hormone gene polymorphism and reproductive traits. BABT.,45: 293-299.

Yao J, Aggrey SE, Zadworny D, Hayes JF, Kuhnlein U. 1996. Sequence variations in the bovine growth hormone gene characterized by single-strand conformation polymorphism (SSCP) analysis and their association with milk production traits in Holsteins. Genetics, 144: 1809-1816.

Yeh F, Yang RC, Boyle T. 2000 Popgene(v.1.32), Microsoft windows-based freeware for population genetic analysis. http://www.ualberta.ca/ fyeh/ Pop32.exe

Yurnalis A, Putra DE. 2017. Polymorphism of Insulin-like Growth Factor 1 Gene (IGF1/TasI,

IGF1/SnaBI, IGF1/RsaI) and the Association with Daily Gain of Pesisir Cattle Local Breed from West Sumatera, Indonesia. Pak J Biol Sci. 2017;20(4):210-216. doi: 10.3923/pjbs.2017.210.216.

Zhou GL, Liu HG, Liu C, Guo SL, Zhu Q, Wu YH. 2005. Association of genetic polymorphism in GH gene with milk production traits in Beijing Holstein cows. J. Biosci.,30: 595-598. 